\title{
The Cost of Corruption in Higher Education
}

\author{
STEPHEN P. HEYNEMAN, KATHRYN H. ANDERSON, AND NAZYM NURALIYEVA
}

Corruption was symptomatic of business and government interactions in Russia and other countries of the former Soviet Union before and during the economic transition of the 1990s. Corruption is difficult to quantify, but the perception of corruption is quantifiable. Nations can even be arranged along a hierarchy by the degree to which they are perceived as being corrupt, for instance, in their business practices or in the administration of public responsibilities. Based on the Transparency International Corruption Perceptions Index for 2005, a world map (see online appendix fig. A1) shows how pervasive corruption remains in the public sector. ${ }^{1}$ According to this index, countries in the former USSR region, including Central Asia and the Caucasus, were among the most corrupt countries in the world in 2005 . $^{2}$

With the breakup of the USSR and decentralization, ministries and local governments operated more independently than under the planned economy. The central government's enforcement mechanisms weakened, and rent-seeking (using administrative position for personal gain) activity was not as effectively monitored as under central planning. The result, at least in the earliest years of independence, was an increase in overall corruption and inefficiency at many levels of government and administration, and the education sector was not immune from these forces (Shleifer and Vishny 1993; Shleifer and Treisman 2005). Ministry of Education officials began to demand bribes for accreditation and procurement. ${ }^{3}$ Administrators demanded bribes for admission, housing, book rental, grades, exams, and transcripts. Teachers demanded bribes for admission, grades and exams, and book purchases.

Anecdotal evidence suggests that the level of education corruption in the USSR was lower than in other sectors. The "fairness" of the system, particularly to children of proletarian origins and minorities, was manifest as a philosophy. During the economic transition, the central authority in education broke

\footnotetext{
${ }^{1}$ The Web address for the map and other information about the Corruption Perceptions Index is http://www.transparency.org/policy_research/surveys_indices/cpi/2005.

${ }^{2}$ The Corruption Perceptions Index "is a composite index, a poll of polls, drawing on corruptionrelated data from expert and business surveys carried out by a variety of independent and reputable institutions. The CPI reflects views from around the world, including those of experts who are living in the countries evaluated" (Transparency International 2006, 9).

${ }^{3}$ In this article we refer to corruption as implying monetary bribery. However, corruption also includes nonmonetary corruption: the illegal changing of student grades or examination scores for reasons of doing "a favor" in support of family, friends, or important personalities.
}

Electronically published November 16, 2007

Comparative Education Review, vol. 52, no. 1.

(C) 2007 by the Comparative and International Education Society. All rights reserved.

0010-4086/2008/5201-0003\$10.00 
HEYNEMAN, ANDERSON, AND NURALIYEVA

TABLE 1

Types of Corruption in Education by Buyer and Seller

\begin{tabular}{lllr}
\hline & & \multicolumn{1}{c}{ Buyers } & \\
\cline { 2 - 4 } Seller & \multicolumn{1}{c}{ Rectors } & \multicolumn{1}{c}{ Students } & Suppliers \\
\hline Ministry of Education & Accreditation & & Procurement \\
Rector & & $\begin{array}{l}\text { Entrance examinations } \\
\text { Library services }\end{array}$ & \\
Other administration & $\begin{array}{l}\text { Housing services } \\
\text { Entrance examinations } \\
\text { Exam grades } \\
\text { Delayed approval of theses } \\
\text { Faculty }\end{array}$ & $\begin{array}{l}\text { Class grades } \\
\text { Book sales }\end{array}$ & \\
\hline
\end{tabular}

down, and the various agents (ministry officials, rectors, faculty, and staff) no longer acted in concert. Decentralization and privatization did not reduce bribe taking but may have significantly increased it. The increase was particularly rapid if international competition from private education providers was restricted. ${ }^{4}$ The quality of education was likely to deteriorate during this phase because individual rent-seeking behavior by agents increased.

Local private providers of educational goods and services entered the market, and this sometimes included foreign providers. The new suppliers provided education in the local language or a foreign language. The owners were local, foreign selling a local product, or foreign selling a "branded product." ${ }^{5}$

Today, the causes and the mechanisms of education corruption are quite varied. Bribes may be obtained in eight different ways (table 1). In the case of procurement and accreditation, the buyer is the educational institution, and the seller of the bribe is the government, usually the Ministry of Education. In the case of obtaining illegal entrance to specialized programs, having grades raised on the grounds of an illegal payment, or paying illegally for normal educational services (housing, library use, and administrative procedures $),{ }^{6}$ the buyer is the student, and the seller is either a faculty member or the administration of the university. The agents vary but can be broadly classified as teachers, rectors and other administrators, and the Ministry of Education.

\footnotetext{
${ }^{4}$ Examples include Tajikistan and Uzbekistan. See Iveta Silova et al. (2007).

${ }^{5}$ The hierarchy in price and prestige normally includes four categories of institutions: (i) local institutions (public or private) that, for instance, supply a business degree in the local language; (ii) local institutions that supply a business degree in an international language; (iii) international institutions with unknown names that supply a business degree in an international language; and (iv) an international institution with a well-known "brand name" that supplies a business degree in an international language.

${ }^{6}$ Students are sometimes required to show their teacher that they bought the textbook authored by the teacher (rather than using a borrowed book) from a store before they are allowed to take the final examination. Postgraduate students may be asked for a bribe before a member of the dissertation committee will agree to sign off on their doctoral thesis.
} 
From the perspective of social development, corruption in education can be worse than corruption in the police, customs service, or other areas because it contains both immoral and illegal elements and involves either minors or young people. Much of education corruption is classified under the term "professional misconduct." Professional misconduct is behavior that breaks the code of conduct normally pertaining to the university professorate (Braxton and Bayer 1999). But "corruption" contains elements beyond the professional behavior. It may include corruption on the part of institutions. Educational institutions that pay a bribe to be accredited (Heyneman 2003, 2004a) may turn out graduates whose skills and professional levels could be a danger to the public. Educational institutions that commit fraud cheat the public because they collect an illegal rent and they commit a crime within the very same institution that was established to select future leaders on a fair and impartial basis (Noah and Eckstein 2001; Heyneman 2005).

Corruption can be efficiency-improving in instances in which prices (tuition, fees, or wages) are distorted by regulation or lags in application. ${ }^{7}$ However, the social benefits from corruption are less likely to be observed in education because corruption affects all the other social goals for making the education investment (Bardhan 1997). Because education serves as a way to model good behavior for children or young adults, allowing an education system to be corrupt may be more costly than allowing corruption in the customs service or the police. By design, one function of education is to purposefully teach the young how to behave in the future. If the education system is corrupt, one can expect future citizens to be corrupt as well. This clearly must have a cost.

Efficiency also fails within an educational institution if corrupt officials are affected by nonpecuniary factors such as favoritism toward one's ethnic, regional, or religious group. In this case, university officials admit unqualified students and faculty, and education becomes a high-price, low-quality good. Instead of increasing the competition within the university, bribery limits competition and reduces quality (Bardhan 1997).

If a college or university acquires a reputation for having faculty or administrators who accept bribes for entry, grades, or graduation, the power of the university in the labor market may be adversely affected. In domestic labor markets, particularly those with many state-run enterprises, the risk is less because the job choices of graduates are fewer. But in the private sector and particularly with companies that draw from international labor markets, the effect of a reputation for corruption on a university may be more serious.

\footnotetext{
${ }^{7}$ Christopher Ahlin and Pataki Bose (2007) demonstrate that partially honest bureaucrats for whom bribery is efficiency-improving in a static framework contribute to economic inefficiency when corruption is modeled as a dynamic process, and consumers have to reapply continuously for permits and licenses. Among other things, this suggests that when normative (often centralized) structures are loosened, wide variations in cultural definitions of corruption emerge.
} 
But how common is the perception of corruption? And how different is the perception of corruption from the actual experience of corruption?

\section{Corruption and Higher Education in Europe and Central Asia}

Incidence of Corruption: Empirical Evidence

Surveys of university students from Serbia, Croatia, Bulgaria, and Moldova were sponsored by local student organizations. Random samples of university students were asked about their knowledge of corruption in admissions, grading, and housing and their attitudes toward corruption. A large number of these questions were identical in all four surveys, but in Serbia in particular, additional questions were included to better identify the corrupt agents and buyers within universities.

We also examine more limited information from Kazakhstan and the Kyrgyz Republic in Central Asia. The Kazakhstan data are from one foreignmanaged university and are the teaching evaluation records for all faculty in 2001/2 and 2004/5. Of the five questions asked, one focused on bribery. The second source of information is surveys of higher-education institutions in the Kyrgyz Republic conducted by the Eberts Fund. We do not have the individual evaluations from these institutions, however, and rely on tabulations from public reports on corruption within these institutions. ${ }^{8}$

Students at universities in six countries through the Anti-Corruption Student Network in Southeastern Europe surveyed randomly selected samples of students at institutions throughout their countries on their experiences with and attitudes toward corruption in education. ${ }^{9}$ In Bulgaria, Serbia, Croatia, and Moldova, significant corruption is evident in admissions and for grades (see table 2). Of the students in Bulgaria, Moldova, and Serbia, between 79 and 84 percent were aware of the practice of illegal bribes to gain admission (i.e., 16-20 percent had "never heard" of such bribes). Between 35 and 45 percent thought that the official selection process could be bypassed, and between 28 and 36 percent thought that admission test scores could be changed. On average, between 18 and 20 percent of the students in Bulgaria, Croatia, and Serbia and 40 percent of the students in Moldova reported that they had used some illegal method to gain admission to their university.

Many of the students in all four countries had a rather fatalistic sense about corruption. Few students said that they would report cheating if they observed it, most would cheat if they could get away with it, and few would

\footnotetext{
${ }^{8}$ None of the surveys collected information on bribery where the buyer was the institution. We therefore have no information on corruption in accreditation or procurement.

${ }^{9}$ The following link provides information on this organization and its programs: http:// www.soros.org/initiatives/hesp/focus/sesi/network_anti. Students were responding to different surveys asking about cheating. The surveys were not coordinated from a single source, and hence the students might have differing concepts about the meaning of cheating. However, all seemed to know that, though common, it was an infraction of the rules.
} 
COST OF CORRUPTION IN HIGHER EDUCATION

TABLE 2

University STUdent Opinions about Corruption (\%)

\begin{tabular}{lcccc}
\hline & Bulgaria & Croatia & Moldova & Serbia \\
\hline $\begin{array}{l}\text { Never heard of illegal methods of } \\
\text { admission }\end{array}$ & 21 & 40 & 21 & 16 \\
$\begin{array}{l}\text { Thought there was bypassing of the } \\
\text { official selection process }\end{array}$ & 37 & 35 & 38 & 45 \\
$\begin{array}{l}\text { Faculty who would illegally change } \\
\text { admission test scores }\end{array}$ & 33 & $28^{*}$ & $36^{*}$ & 36 \\
$\begin{array}{l}\text { Students who use some illegal } \\
\quad \text { method of admission }\end{array}$ & 18 & 18 & 40 & $\ldots$ \\
$\begin{array}{l}\text { Students who buy admission exam } \\
\text { results }\end{array}$ & 9 & 3 & $\ldots$ & 6 \\
$\begin{array}{l}\text { Students who knew of bribery for a } \\
\text { grade or an exam among their } \\
\text { faculty }\end{array}$ & 60 & 62 & 80 & 66 \\
$\begin{array}{l}\text { Students who said they would offer } \\
\text { a bribe to receive a certain grade }\end{array}$ & 17 & 15 & 31 & 20 \\
$\begin{array}{l}\text { Students who said they had ever } \\
\text { paid for an exam or grade }\end{array}$ & 7 & .5 & 28 & 4 \\
\hline$\quad *$ Question is "Possibilities for admission test scores to be illegally changed." & &
\end{tabular}

TABLE 3

How Do You Feel about Cheating? (Percent Answering Yes)

\begin{tabular}{lcccc}
\hline & Bulgaria & Croatia & Moldova & Serbia \\
\hline $\begin{array}{l}\text { Would you feel bad after cheat- } \\
\text { ing on an examination? }\end{array}$ & 20 & 25 & 35 & 22 \\
$\begin{array}{l}\text { If you would be in a situation to } \\
\text { cheat without getting caught, } \\
\text { would you cheat? }\end{array}$ & 60 & 76 & 67 & 69 \\
$\begin{array}{l}\text { Have you heard about cheating } \\
\text { on exams in your university? }\end{array}$ & 77 & 73 & 59 & 79 \\
$\begin{array}{l}\text { Should students allow their tests } \\
\text { to be copied? }\end{array}$ & 80 & 75 & 65 & 78 \\
\hline
\end{tabular}

feel badly about it (see table 3). Nevertheless, even in circumstances in which cheating is the "norm," between 11 and 14 percent of the students and faculty "resist" the temptation and consider corrupt behavior to be "unacceptable."

What should be done with those who are caught? Thirty-four percent of the students in Bulgaria thought that they should be expelled; 36 percent of students in Serbia approved of a severe penalty such as expulsion, legal prosecution, jail, and public humiliation. However, 90 percent of the students did not know the penalty for faculty who are caught accepting a bribe, and 87-90 percent of them did not know the penalty for students who cheat (Posliyski and Vatev n.d.).

In a study of students at local universities in the Kyrgyz Republic, the majority of students in most of the universities described their institutions as being "bribable" (see table 4). A private university managed by foreign owners, in accordance with international standards of professional conduct, might be expected to have significantly less corruption than in government 
HEYNEMAN, ANDERSON, AND NURALIYEVA

TABLE 4

University Students in the Kyrgyz Republic Who Describe Their University AS BRIBABle

\begin{tabular}{lc}
\hline & $\%$ \\
\hline Kyrgyz Technical University & 68.0 \\
Kyrgyz Agrarian University & 67.5 \\
National State University & 64.9 \\
Bishkek State University & 62.0 \\
Medicine Academy & 59.6 \\
Kyrgyz State University of Construction and Architecture & 59.0 \\
Kyrgyz Slavonic University (Russian) & 51.0 \\
International University in the Kyrgyz Republic & 49.5 \\
Kyrgyz State Physical Culture and Sport Academy & 34.3 \\
American University of Central Asia & 5.1 \\
\hline
\end{tabular}

Source.-Ebert Fund, http://akipress.org/news/26369 (in Russian).

universities. ${ }^{10}$ This is supported by the data in table 4 , where only 5.1 percent of the students at the American University of Central Asia report that their university is "bribable" as opposed to between 50 and 70 percent in local government universities (Ebert Fund, March 2, 2006). ${ }^{11}$

This latter finding is corroborated by evidence from Kazakhstan. Students at a Turkish-owned university were asked if teachers were willing to take gifts and other payments and if the course was professional. ${ }^{12}$ An average of 7 percent of students in 2001 reported that the faculty accepted gifts. However, when the survey was repeated 4 years later the proportion declined to 3.3 percent. There was a significant decline in the percentage of students reporting gift taking or bribery among faculty after instructors knew that this behavior would be reported. Like the American University of Central Asia, the Kazak-Turkish University has a lower incidence of bribery than local state institutions because of the application of external standards of professional conduct to the behavior of faculty and administrators.

Which Disciplines Are More Likely to Accept Bribes?

Within higher-education institutions, there was wide variation in corruption across departments and fields. This is evident in the data from the KazakTurkish University (see table 5). In 2001 gift taking was highest in chemistry, world history, Kazakh literature, language, political science, and economics

\footnotetext{
${ }^{10}$ A foreign university must adhere to two sources of rules and regulations: from the country in which they are situated and in their home country.

${ }^{11}$ In this context "local" implies locally as opposed to internationally accredited universities. It does not imply a subnational geographical unit as in county or region.

${ }^{12}$ The professional quality of the course and the instructor was defined in terms of the quality of lectures and seminars, respect from students, and objectivity in evaluation of a student's progress. The average score of the four professional quality questions was the instructor's rating on professional skill. The faculty did not know in advance that the question on gift taking would be included on the student evaluation form. In the 2004/5 survey of students the faculty knew that the question on gift taking would be included; the gift taking question was changed so that bribery could be separately identified from giving gifts without requiring a favor from the instructor. The revised question was "Did the teacher demand gifts or bribes from you?"
} 
COST OF CORRUPTION IN HIGHER EDUCATION

TABLE 5

Bribery by Departments in the KaZaK-Turkish University, 2001 and 2005

\begin{tabular}{|c|c|c|}
\hline \multirow[b]{2}{*}{ Faculty } & \multicolumn{2}{|c|}{ Percent Taking a Bribe } \\
\hline & 2005 & 2001 \\
\hline Design & 0 & 9.0 \\
\hline Physics & 1.0 & 5.6 \\
\hline Russian language & 1.3 & 4.9 \\
\hline Imitative (fine) arts & 1.7 & 8.4 \\
\hline Information systems & 1.8 & 5.1 \\
\hline Organic and physical chemistry & 2.1 & 16.8 \\
\hline World history & 2.3 & 14.9 \\
\hline Linguistics & 2.4 & 3.1 \\
\hline Study of Turkic & 2.5 & 7.1 \\
\hline Clothing design & 2.6 & 4.4 \\
\hline World literature & 2.6 & 5.3 \\
\hline History of Kazakhstan & 2.7 & 4.0 \\
\hline Kazakh literature & 2.8 & 10.8 \\
\hline Mechanics & 3.0 & 4.6 \\
\hline Physical culture & 3.1 & 7.9 \\
\hline Kazakh language & 3.1 & 9.2 \\
\hline Music and singing & 3.4 & 5.3 \\
\hline General and nonorganic chemistry & 3.7 & 10.1 \\
\hline High mathematics & 3.8 & 6.9 \\
\hline Foreign language & 3.8 & 5.7 \\
\hline Ecology & 3.8 & 0 \\
\hline Political science & 5.0 & 9.5 \\
\hline Biology & 5.2 & 5.9 \\
\hline English language & 5.9 & 3.9 \\
\hline Graphics & 7.8 & 6.9 \\
\hline Economics and management & 10.1 & 8.1 \\
\hline Law & 12.8 & 5.4 \\
\hline
\end{tabular}

SourcE.-Shymkent Institute Sociology Survey, Shymkent, Kazakhstan, 2006.

and lowest in physics, Russian language, and fine arts. Bribery was reported by 16.8 percent of the students in the organic and physical chemistry departments and 8.1 percent in economics. Four years later, the incidence declined in all departments except English language, economics, management, graphics, and law. Reported bribery in economics increased from 8 to 10 percent and in law from 5.4 to 12.8 percent.

In general the disciplines most likely to be characterized by bribery seem to be those in highest demand-law, economics, finance, and criminologywhere the competition to enter is greater, the fees and tuitions are larger, and the stakes for graduating are higher. ${ }^{13}$ Senior officials interviewed in Russia reported that the faculty salary was 50 percent of the wage paid in the private sector for PhD-trained employees in the humanities and 30 percent or lower of the private-sector wage for PhD-trained employees in eco-

\footnotetext{
${ }^{13}$ Tuitions are often higher in vocational certification programs (such as for the customs service), where the opportunities for bribes are greater. Bribery may also be involved when universities seek to be accredited by the Ministry of Education to offer those particular programs.
} 
nomics and law. ${ }^{14}$ The pattern of corruption in the Kazak data is consistent with the evidence from other sources. The probability that an instructor accepts a bribe increases as the difference in the market value of the instructor's wage and the university wage widens. If bribery cannot be detected easily or if sanctions are weak, the probability of bribe taking is even higher (Becker and Stigler 1974; Rose-Ackerman 1975; Shleifer and Vishny 1993; van Rijckeghem and Weber 2001; Sosa 2004). The sanctions imposed for revealed corruption are severe at foreign-operated universities such as the American University of Central Asia or the Kazak-Turkish Institute and include expulsion of students and firing of faculty. ${ }^{15}$ However, in many other universities, corruption is openly practiced, and faculty and students are rarely sanctioned for corrupt behavior. ${ }^{16}$

A similar pattern across the disciplines is observed in Bulgaria and Serbia. Figure 1 shows the percentage of students who bought a textbook as a condition for passing an exam in Bulgaria. It is highest in medicine (58 percent) and dentistry ( 54 percent), followed by chemistry (50 percent), law, history, sociology/political science, economics, and engineering/electronics (40-50 percent). In Serbia the largest sources of corruption also appear to be in medicine, economics, and law (see table 6). Students in these Serbian university departments were more likely to pay other students or faculty to take an exam, to pay a bribe, or be forced to buy a personal textbook by a faculty member, enroll illegally, or experience corruption among administrators than within the university as a whole.

\section{Corruption and Higher-Education Quality}

Corruption, Higher-Education Quality, and Private Economic Returns

Education potentially serves two functions in the labor market. It is an investment in human capital and develops labor productivity. We expect to find that each additional year of higher education increases earnings, because the student acquires new knowledge, skills, and attitudes that are transferable to employment. Both the student and society gain from private investment

\footnotetext{
${ }^{14}$ In the Kyrgyz Republic, e.g., the average faculty salary in universities in the capital city, Bishkek, is about $\$ 50$ a month. This information was obtained from conversations with faculty at several universities. In the poorest region of the country-Naryn oblast-the average take-home faculty salary is $\$ 30$ a month, which, according to one professor of economics, was enough to cover only 2 weeks of living expenses in Naryn.

${ }^{15}$ Here we refer to foreign, publicly operated universities. We might speculate that a similar pattern might occur with foreign, privately operated universities, but we have no firsthand evidence on this as yet.

${ }^{16}$ In several universities, students reported to us that some professors selected a class representative to collect bribes from other students in the class before exams were graded. This differs from a "grading fee" known in other regions because the fees pocketed by the faculty member in this case are done so illegally. All students in the class were aware that a bribe was expected. In other cases, parents sent bribes to professors before their children took their oral exams. The difficulty of these exams depended on the amount of the bribe paid by parents before the exam. The incidence of bribery was close to 100 percent if the course was a correspondence course.
} 


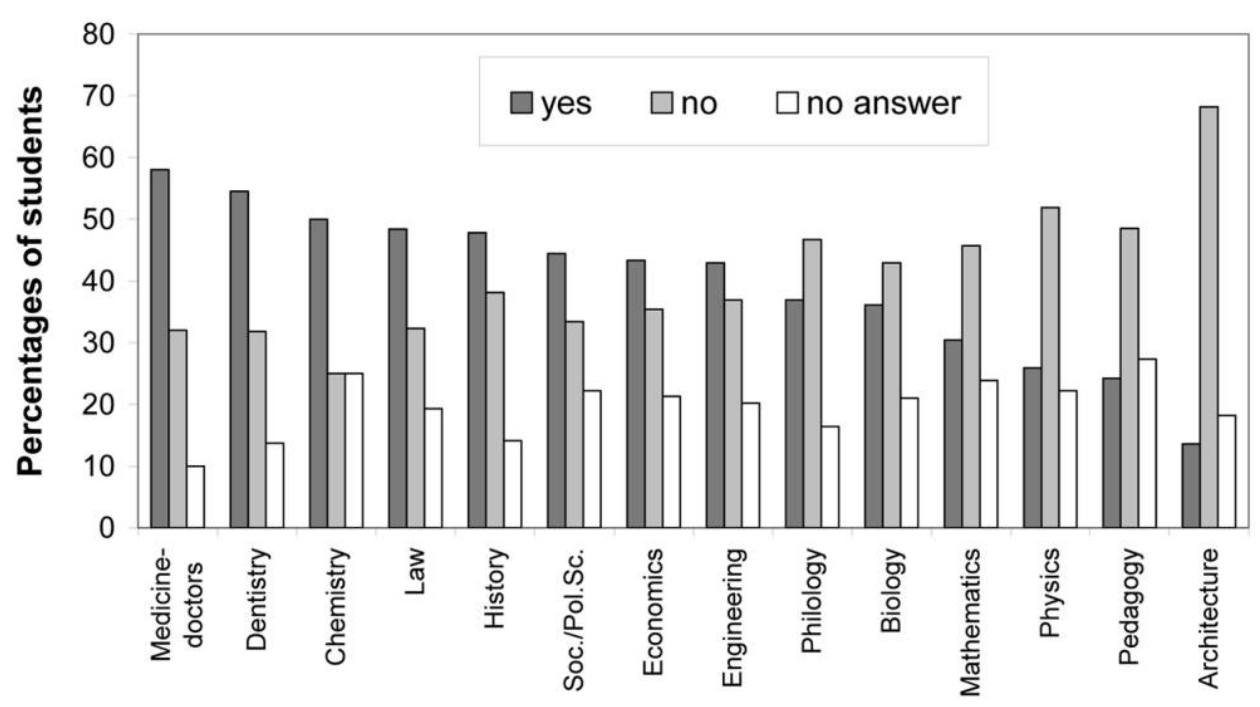

Fig. 1.-Was student required to buy professor's textbook as a condition of passing an exam? Responses by Bulgarian students in 2003. Source: Posliyski and Vatev (2003).

in higher education. Second, completion of education can signal to employers that the student is of high ability and integrity and has great potential to be a productive employee (Heyneman 2002/3) or a status group selectivity marker (Collins 1979). Only the most able students are able to complete higher education because the costs of completion (time, money, and effort) are lower than for other students. Higher education may not increase the productivity of labor directly, but it may help employers sort out the most productive and reliable from other more costly workers. If education signals ability in the labor market, individual investors gain from investments in education, but the benefits to society are small.

Monetary returns associated with different levels of educational attainment are the most common method to gauge economic impact (Griliches and Mason 1972). But educational quality varies significantly from one part of the world to another (Heyneman 2004b), and reliance on measures of educational attainment to quantify impact may be economically misleading (Behrman and Birdsall 1983). Yet valid and reliable measures of highereducation quality are difficult to find for most countries (James et al. 1989). Nevertheless, progress has been made in terms of hammering out common definitions of quality (Welch 1966; Solmon 1975) and exploring the relationship between earnings, educational quality, and individual ability. ${ }^{17} \mathrm{Be}-$ cause it is difficult to directly measure college quality, it has been common to utilize proxy measures. These have included college prestige and selec-

\footnotetext{
${ }^{17}$ See, e.g., Griliches and Mason (1972), Solmon and Wachtel (1975), Kingston and Smart (1990), Brewer et al. (1999), and Dale and Krueger (2002).
} 
HEYNEMAN, ANDERSON, AND NURALIYEVA

TABLE 6

Corruption by Faculty, Serbia, 2003

\begin{tabular}{|c|c|c|}
\hline & $\begin{array}{c}\text { Frequently or Very } \\
\text { Frequently Reported } \\
(\%)\end{array}$ & $\begin{array}{l}\text { Never } \\
\text { Reported } \\
(\%)\end{array}$ \\
\hline \multicolumn{3}{|c|}{$\begin{array}{l}\text { 1. Students who pay another student to take } \\
\text { an exam: }\end{array}$} \\
\hline Economics & 45.5 & 3.5 \\
\hline Medical science & 44.2 & 3.4 \\
\hline Law & 40.5 & 1.6 \\
\hline \multicolumn{3}{|c|}{$\begin{array}{l}\text { 2. Students who pay a professor to take an } \\
\text { exam for them: }\end{array}$} \\
\hline Economics & 12.5 & 13.0 \\
\hline Medical science & 4.9 & 22.8 \\
\hline Law & 9.7 & 15.7 \\
\hline \multicolumn{3}{|c|}{ 3. Students who bribe faculty for a grade: } \\
\hline Economics & 29.5 & 8.5 \\
\hline Medical science & 26.9 & 6.2 \\
\hline Law & 20.5 & 11.9 \\
\hline \multicolumn{3}{|c|}{$\begin{array}{l}\text { 4. Students forced to buy the textbook in or- } \\
\text { der to pass:* }\end{array}$} \\
\hline Economics & 29.5 & 8.5 \\
\hline Medical science & 24.9 & 9.0 \\
\hline Law & 28.1 & 8.6 \\
\hline \multicolumn{3}{|c|}{ 5. Corruption reported in administration: } \\
\hline Economics & 25.5 & 6.0 \\
\hline Medical science & 16.5 & 6.2 \\
\hline Law & 33.4 & 4.9 \\
\hline
\end{tabular}

tivity $^{18}$ type or purpose (Solmon and Wachtel 1975) and one's individual course of study (Link 1973; Rumberger and Thomas 1993). While most studies have found that higher quality is associated with higher salaries, some have wondered whether the effect on earnings is through the use of college as a screening device (Psacharopoulos 1974; McGuinness 2003a) and the result of natural ability rather than college quality (Hause 1971, 1972; Griliches and Mason 1972).

Whichever proxy has been chosen, college quality has generally been found to be positively associated with lifetime earnings. ${ }^{19}$ In one study, the rate of return to investment in college varied from a low of 2.5 percent to a high of 15.6 percent depending on the measure of college quality (Ono 2004, 612).

Corruption affects the private and social return to education investment through both of these paths. If students purchase grades, for example, students have less incentive to learn. Advancement is less correlated with knowledge and the acquisition of skill than with wealth and the ability to pay for

${ }^{18}$ See, e.g., Mueller (1988), Kingston and Lewis (1990), Kingston and Smart (1990), Brewer et al. (1999), and Strayer (2002).

${ }^{19}$ See, e.g., Wales (1973), Hilmer (2002), Strayer (2002), and McGuinness (2003b). 
achievement. The private and social returns to higher education are degraded. The signaling function of education is also reduced if there is significant corruption among faculty and administrators. Completion of education cannot be closely linked to the ability of students if entry into programs and high grades are for sale. The employer does not know whether the student completed the program and did well because she was a high-ability, low-cost student or because she acquired grades illegally or unfairly. The variance in ability of students completing a corrupt program is higher than for students who do not complete a corrupt program. Even if an individual student from a relatively corrupt institution is honest and of high ability, the signaling value of the degree is reduced. ${ }^{20}$ An employer with a choice of candidates reduces the risk of hiring an unproductive employee by avoiding graduates of corrupt institutions and programs and hiring only students from institutions, departments, or programs with a reputation for honesty. For this employer to hire a student from a corrupt program, the student would have to accept a significantly lower salary and prove his or her economic value to the employer through on-the-job experience.

Corruption in undergraduate institutions affects the probability that a student can obtain a graduate degree. Graduate schools, particularly in Western universities, discount applicants from institutions in which corruption is perceived as common. Applicants from corrupt programs are less likely to be selected because grades and test scores do not represent their ability to do graduate-level work.

When employers know the level of corruption within higher-education institutions and across programs within these institutions, then we expect employment and earnings to be positively affected by attending a university with a low level of corruption among its faculty and staff. ${ }^{21}$ The productivity and signaling functions are illustrated through a standard earnings functions given in equation (1) below:

$$
\ln \left(W_{i t}\right)=\ln \left(W_{0}\right)+\beta_{1} S_{i t}+\beta_{2} X_{i t}+\beta_{3} Z_{i t}+\varepsilon_{i t}
$$

The logarithm of earnings $(W)$ of employee $i$ at time $t$ is a function of education $(S)$, market experience $(X)$, and other observable characteristics $(Z)$ of $i$ that affect employment and wage decisions. The term $\beta_{1}$ is the annual rate of return to each year of investment in education if $S$ is measured as

\footnotetext{
${ }^{20}$ While corruption may lower the signaling value of a degree in the private sector, a degree creates a different kind of signal in the marriage market in some of the rural, more traditional areas of the region. In interviews with local officials in Osh and Djalalabad oblasts in the Kyrgyz Republic, we were told that parents bought college degrees, including master's degrees, for a daughter in order to signal that she was from a wealthier family. Education degrees increased her value in the marriage market, and her family would benefit from making a better match for their daughter.

${ }^{21}$ Not all employers view education corruption in an identical fashion. International companies with transnational access to employees might be most concerned and, hence, the most selective. Private non-state-owned enterprises similarly would be concerned. State-owned enterprises and the public sector might be the least concerned. Our interviews with employers were drawn from the second category.
} 
years of schooling; $\beta_{1}$ is affected by corruption $(C)$ within the education institutions attended by $i$. If corruption lowers the quality of education and, therefore, the productivity of labor, then corruption lowers the return to education. If, however, corruption in education helps to "grease the wheels" in the labor market and provides workers with entry into more lucrative, and possibly corrupt, jobs, the return to education could be higher if corruption in education is pervasive. If education has less value in the labor market if it is obtained through corruption, then employers may place a higher weight on other noneducational productivity-related characteristics of workers such as previous work experience, health, and marital status in their employment decisions. The returns to experience and other productivity characteristics $\left(\beta_{2}\right)$ may increase in the presence of corruption. In general, $\beta_{k}=f(C)$, $k=1,2, \partial \beta_{1} / \partial C<0$, and $\partial \beta_{2} / \partial C>0$ if $S$ and $X$ increase the earnings of employee $i$. This model is similar to the education quality models of Charles Link (1973) and others.

With information on individual earnings, completion of education, corruption in education, and other characteristics of individuals, equation (1) can be estimated with linear regression with inclusion of interactions between the quantity and quality (corruption) of education to measure the impact of corruption on education returns. The empirical model is given in equation (2):

$$
\ln \left(W_{i t}\right)=a+b_{1} S_{i t}+c_{1}(S C)_{i t}+b_{2} X_{i t}+c_{2}(X C)_{i t}+b_{3} Z_{i t}+e_{i t},
$$

where $a, b_{j}$, and $c_{j}(j=1,2,3)$ are estimated regression coefficients. The return to years of education in the absence of corruption is $b_{1}(>0)$, and the presence of corruption lowers this return to $b_{1}+c_{1} C$ if $c_{1}<0$ and $C$ is positive. If employers put more weight on other productivity-related characteristics $(X)$ in the presence of corruption $\left(c_{2}>0\right)$, then the impact of $X$ on the $\log$ wage increases to $b_{2}+c_{2} C^{22}$ For example, employers may place greater value on previous experience if corruption in education is widespread

\footnotetext{
${ }^{22}$ Equations (1) and (2) assume that the level of corruption is exogenous to the wage and is not affected by the unobserved characteristics of workers such as their inherent honesty or ability. This is not likely to be the case for several reasons. Those students who are willing to pay a bribe are more likely to be selected from the lower tail of the ability distribution and have other sources of income, possibly obtained through illegal transactions or corruption in the market. Professors who accept bribes are also not randomly selected from the population of professors but are more likely to be drawn from fields that are in high demand, pay a low salary relative to their value in the outside market, and are from the lower tail of the teaching ability distribution. If a professor graduates highly productive students, this signals her productivity to the private sector and can lead to additional income through outside contracts, grants, and part-time employment. The professors who are of lower ability and have low value in the outside market are more likely to demand bribes to compensate them for their lack of skill. In this case, regression estimation of eq. (2) produces biased estimates of returns to education with and without corruption. If the fixed-effect component of the residual is correlated with corruption perceptions, then the fixed-effects regression model we estimate minimizes this bias. The Transparency International data that we use do not contain any variables that we can use to otherwise identify corruption perceptions through instrumental variables estimation. In future surveys of the perception of education corruption, uniform definitions would help to reduce the risk of having variations in interpretation.
} 
because these workers have a productivity track record. Or employers may place greater weight on the youngest workers because they have had less experience with corruption than older workers. We try to empirically determine whether these changes occur.

Data and Estimation

To estimate model (2), we use data on corruption in education from the Transparency International (TI) Global Corruption Barometer 2005. The data were collected from public opinion surveys between May and October 2005 conducted by the Gallup Organization for Transparency International. Over 55,000 people in 69 countries were interviewed face-to-face or over the telephone. ${ }^{23}$ To the extent possible, samples were randomly selected and, in most countries, were conducted nationally. In some countries only persons in urban areas (e.g., Thailand) or the main city (e.g., Georgia) were included in the survey. Francis Hutchinson et al. (2005) provide more information on the surveys and the survey results.

The dependent variable in equation (2) is the log of income. However, in the TI data, income is a categorical variable and can take one of three values: $1=$ low to medium-low income, $2=$ medium to medium-high income, and $3=$ high income. We estimate two versions of model (2). In the first version, we try to predict whether a person will have high income. The dependent variable is a dummy variable equal to one if the individual reports high income and zero for low or medium income. In the second version of the model, we try to predict whether a person will have a low income. The dependent variable is a dummy variable equal to one if the individual reports low income and zero for high or medium income. By estimating both models, we can get a better picture of how corruption in education affects economic well-being.

The measure of education corruption $(C)$ that we use from this survey is based on perceptions of corruption in education. The question was asked: To what extent do you perceive the education sector in this country is affected by corruption? The scale is from 1 to 5 , where $1=$ not at all corrupt and $5=$ extremely corrupt. There is no information in the survey on the respondent's actual experience with corruption.

The data on education and other personal characteristics of workers are limited and categorical. Education $(S)$ is measured with two dummy variables: completion of secondary education and completion of higher education relative to no or basic education. Other characteristics include age (less than $30,51-65$, and greater than 65 in comparison to ages 31-50), gender $(1=$ male, $0=$ female), and region (Western Europe, Central and Eastern Eu-

\footnotetext{
${ }^{23}$ The countries from the Eastern European and Eurasian region are Bosnia-Herzegovina, Bulgaria, Croatia, the Czech Republic, Georgia, Kosovo, Lithuania, Macedonia, Moldova, Poland, Romania, Russia, Serbia, and Ukraine.
} 


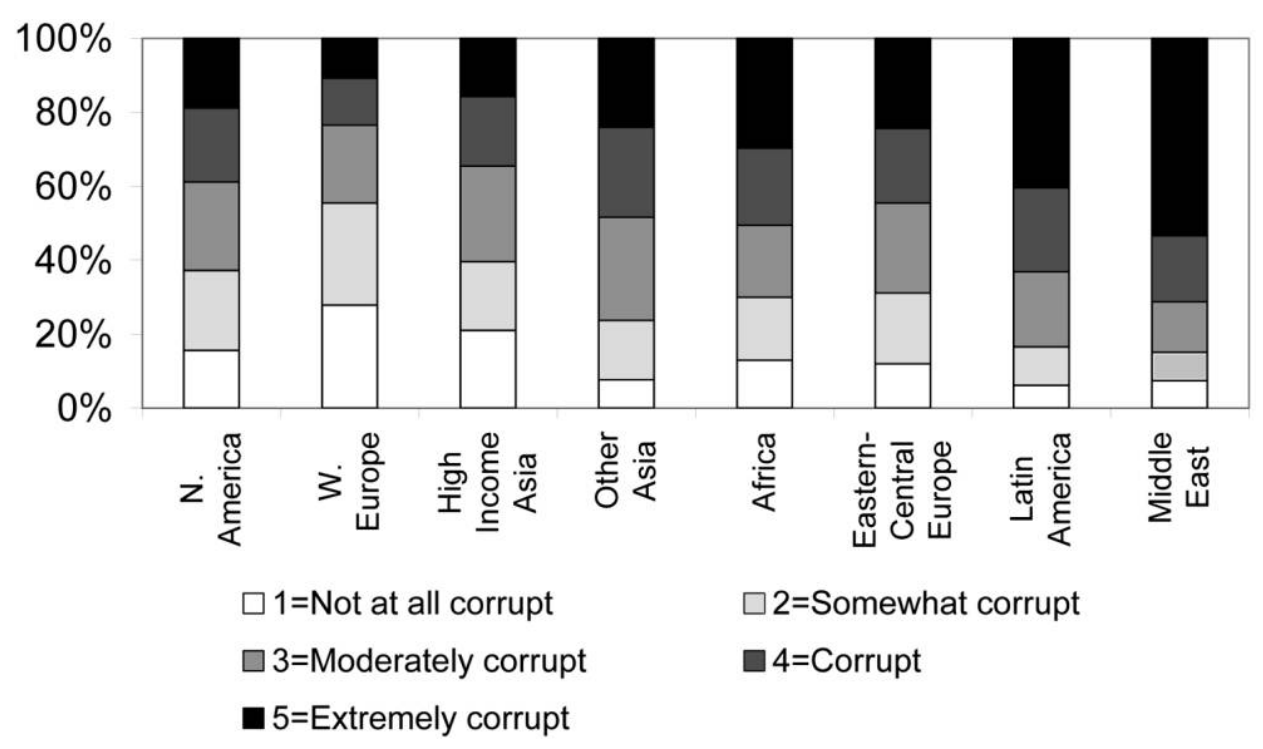

FIG. 2.-Perceptions of corruption in education across regions

rope, Latin America, Asia and Pacific, Middle East, Africa, and North America). We also include two variables that control for the overall corruption environment in each country. The first variable measures whether corruption affects political life $(1=$ not at all, . . , 5 = extremely corrupt $)$, and the second variable measures whether corruption decreased over the last 3 years $(1=$ increased a lot, . . ., $4=$ decreased a lot $)$.

We include in equation (2) interactions between secondary and higher education and education corruption $(C)$. The coefficients on the interactions between corruption and education indicate whether corruption in education affects the impact of investments in secondary and higher education on income $\left(c_{1}\right)$. Equation (2) also includes interactions between corruption and age and gender, and the coefficients on the interactions indicate whether corruption in education affects the impact of experience and gender on income $\left(c_{2}\right)$. Our sample includes 36,404 persons from 68 countries who are under the age of 65 and have complete data on income, corruption, education, and age; no one from the Chinese sample is included because data on income were not collected. About 45 percent of the people in our sample report low income or medium income, and almost 15 percent have high income. About half of the sample has completed secondary education, with an additional 18 percent with only basic education and 31 percent with higher education. The average education corruption perceptions score is 3.3.

Figures 2 and 3 illustrate the variation in perceptions of corruption in education across regions and, specifically, within Eastern and Central Europe and Central Asia (ECA). In the highest-income countries, less than 40 percent 
COST OF CORRUPTION IN HIGHER EDUCATION

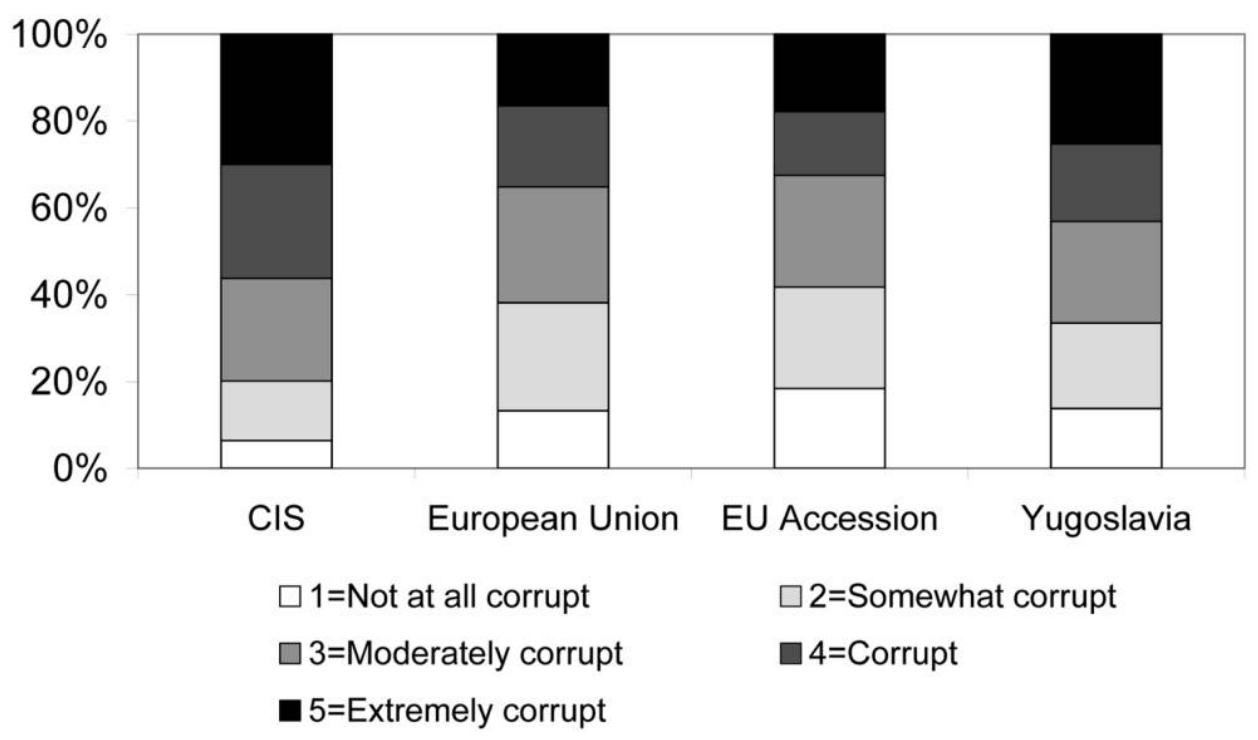

Fig. 3.-Perceptions of corruption in education in Eastern Europe, Central Europe, and Central Asia

of respondents report high levels of corruption (4 or 5). Corruption in education is significantly higher in the other regions: in Latin America and the Middle East over 60 percent of respondents report a high level of corruption. Within the EC region, corruption is highest among the countries of the Commonwealth of Independent States (CIS) (Russia, Moldova, Ukraine) and Georgia and lowest among the countries of the European Union (Lithuania, Czech Republic, Poland) and in EU accession countries (Bulgaria, Romania). ${ }^{24}$

Because the income variable is a categorical variable, we estimate equation (1) with a linear probability model. The term $Y_{i j}$ is the income indicator variable and is equal to one if individual $i$ in country $j$ reports either high income or not poor (medium or high income) and zero otherwise. We regress $Y$ on two education variables $\left(S_{\text {sed }}\right.$, $\left.S_{\text {hed }}\right)$, age, gender, political corruption, and the change in corruption $(Z)$, and the interactions between education corruption and education, age, and gender. The random error is assumed to have two components: a person-invariant, country fixed effect $\left(v_{j}\right)$ and an individual-specific random error $\left(e_{i j}\right)$. The country fixed effect measures tastes and cultural, social, and economic norms in country $j$ that are common to all persons in $j$ and likely affect perceptions of corruption, educational achievement, and the reported level of income. To eliminate the influence

\footnotetext{
${ }^{24}$ Pairwise difference in variance tests (Levene and Brown and Forsythe robust tests) indicate significant differences in the spread within the regional distributions. The ECA region displays more variation in corruption perceptions than Western Europe, Latin America, lower-income Asia, and the Middle East and less variation than the other regions. Within the ECA region, variation in perceptions is lowest in the CIS countries and highest in the countries of the former Yugoslavia.
} 
of these country effects on the estimate of the coefficient vector $B$, we estimate our model as a fixed-effects model with robust standard errors. The fixedeffects model is given in equation (3) below:

$$
Y_{i j}=X_{i j} B+v_{j}+e_{i j}
$$

We report the marginal effects of educational attainment on the probability of high income (table 7) and on the probability of low income (table 8) when there is no corruption and when corruption is maximum (5).$^{25}$ The marginal effects of secondary education and higher education are relative to primary education. The cells are in boldface if corruption in education directly changes the impact of secondary or higher education relative to primary education on income. ${ }^{26}$ We compare the effects of secondary and higher education with no corruption in education to the effects under maximum corruption (5). We expect to find that those individuals with higher education are more likely to be poor and less likely to have high income when corruption in education increases.

In high- and lower-income Asian countries, Eastern and Central Europe, and Western Europe, secondary education over basic education in the absence of corruption in education increases the probability of high income, and the effect ranges from .05 higher in the lower-income Asian countries to .18 higher in the high-income Asian countries. The secondary education effect is .05 over all countries; on average, secondary education increases the probability of high income by .05 or 5 percent over basic primary education. In all regions except the Middle East and in the absence of corruption, completion of higher education has a large impact on the probability of high income. On average, higher education in comparison to secondary education increases the probability of high income by about .2. The marginal effect of higher education ${ }^{27}$ is highest in North America and the high-income countries of Asia. Within the ECA region, the marginal effect of higher education is also .20 and is slightly lower among the CIS countries at $.18 .^{28}$ The highest benefit from higher education in the ECA region is found in the EU accession countries.

The education results for the low-income models mirror the high-income results, but the effects are larger. In all regions except Africa, completion of secondary education over primary education decreases the probability of

\footnotetext{
${ }^{25}$ In the Middle East and the new European Union, EU accession, and former Yugoslavian countries, there was no effect of education corruption on high or low income.

${ }^{26}$ We assume that an insignificant coefficient has a value of zero in the calculations in tables 7 and 8 .

${ }^{27}$ The marginal effect of higher education is defined relative to the next-lowest level of completed education-secondary education. The higher-education regression coefficient is interpreted relative to basic primary education.

${ }^{28}$ The CIS consists of the countries of the ECA region except the three Baltic states of Lithuania, Latvia, and Estonia.
} 
TABLE 7

Educational Corruption, Educational Attainment, and the Probability of High Income

\begin{tabular}{|c|c|c|c|c|c|c|}
\hline \multirow[b]{2}{*}{ Country } & \multicolumn{3}{|c|}{ No Corruption $(C=0)$} & \multicolumn{3}{|c|}{ Maximum Corruption $(C=5)$} \\
\hline & $\begin{array}{c}\text { Secondary } \\
\text { Education } \\
\text { vs. Basic: } \\
b_{\mathrm{sec}} \\
\end{array}$ & $\begin{array}{c}\text { Higher } \\
\text { Education } \\
\text { vs. Basic: } \\
b_{\text {hed }} \\
\end{array}$ & $\begin{array}{c}\text { Higher } \\
\text { Education } \\
\text { vs. Secondary } \\
\text { Education: } \\
b_{\text {sed }}-b_{\text {hed }} \\
\end{array}$ & $\begin{array}{c}\text { Secondary } \\
\text { Education } \\
\text { vs. Basic: } \\
b_{\text {sed }}^{*}=b_{\text {sed }}+b_{s c} C\end{array}$ & $\begin{array}{c}\text { Higher } \\
\text { Education } \\
\text { vs. Basic: } \\
b_{\text {hed }}^{*}=b_{\text {hed }}+b_{h c} C \\
\end{array}$ & $\begin{array}{c}\text { Higher } \\
\text { Education } \\
\text { vs. Secondary } \\
\text { Education: } \\
b_{\text {hed }}^{*}-b_{\text {sed }}^{*}\end{array}$ \\
\hline All & .049 & .244 & .195 & .049 & .154 & .105 \\
\hline Western Europe & .110 & .275 & .165 & .050 & .175 & .125 \\
\hline North America & .000 & .307 & .307 & .000 & .102 & .102 \\
\hline \multicolumn{7}{|l|}{ Asia: } \\
\hline High income & .180 & .450 & .270 & .180 & .265 & .085 \\
\hline Lower income & .046 & .223 & .177 & .046 & .223 & .177 \\
\hline Africa & .000 & .207 & .207 & .000 & .057 & .057 \\
\hline Latin America & .000 & .076 & .076 & .000 & .076 & .076 \\
\hline ECA & .071 & .276 & .205 & .071 & .276 & .205 \\
\hline CIS & .000 & .183 & .183 & .000 & .183 & .183 \\
\hline
\end{tabular}

NotE. - Boldface indicates that corruption changes the effect of education on the probability of high income. Corruption can change the effect of secondary education or highe education in comparison to primary, and it can change the effect of higher education relative to secondary. The latter can result from a change in the effect of secondary relative to primary, higher education relative to primary, or both. The boldface indicates what is behind the 
TABLE 8

Educational Corruption, Educational Attainment, and the Probability of Low Income

\begin{tabular}{|c|c|c|c|c|c|c|}
\hline \multirow[b]{2}{*}{ Country } & \multicolumn{3}{|c|}{ No Corruption $(C=0)$} & \multicolumn{3}{|c|}{ Maximum Corruption $(C=5)$} \\
\hline & $\begin{array}{c}\text { Secondary } \\
\text { Education } \\
\text { vs. Basic: } \\
b_{\text {sec }} \\
\end{array}$ & $\begin{array}{c}\text { Higher } \\
\text { Education } \\
\text { vs. Basic: } \\
b_{\text {hed }} \\
\end{array}$ & $\begin{array}{c}\text { Higher } \\
\text { Education } \\
\text { vs. Secondary } \\
\text { Education: } \\
b_{\text {sed }}-b_{\text {hed }} \\
\end{array}$ & $\begin{array}{c}\text { Secondary } \\
\text { Education } \\
\text { vs. Basic: } \\
b_{\text {sed }}^{*}=b_{\text {sed }}+b_{s c} C\end{array}$ & $\begin{array}{c}\text { Higher } \\
\text { Education } \\
\text { vs. Basic: } \\
b_{\text {hed }}^{*}=b_{\text {hed }}+b_{h c} C\end{array}$ & $\begin{array}{c}\text { Higher } \\
\text { Education } \\
\text { vs. Secondary } \\
\text { Education: } \\
b_{\text {hed }}^{*}-b_{\text {sed }}^{*} \\
\end{array}$ \\
\hline All countries & -.177 & -.349 & -.172 & -.177 & -.349 & -.172 \\
\hline \multicolumn{7}{|l|}{ High-income countries: } \\
\hline Western Europe & -.239 & -.336 & -.097 & -.104 & -.336 & -.232 \\
\hline North America & -.312 & -.392 & -.080 & -.312 & -.392 & -.080 \\
\hline Asia, high income & -.277 & -.499 & -.222 & -.277 & -.499 & -.222 \\
\hline \multicolumn{7}{|l|}{ Lower-income countries: } \\
\hline Asia, lower income & -.094 & -.379 & -.285 & -.239 & -.379 & -.140 \\
\hline Africa & .000 & -.224 & -.224 & -.070 & -.224 & -.154 \\
\hline Latin America & -.144 & -.313 & -.169 & -.144 & -.433 & -.289 \\
\hline ECA countries & -.175 & -.416 & -.241 & -.175 & -.326 & -.151 \\
\hline CIS & .000 & -.401 & -.401 & -.130 & -.241 & -.111 \\
\hline
\end{tabular}

NotE. - Boldface indicates that corruption changes the effect of that level of education on the probability of low income. If the marginal higher education effect changes but is not in boldface, this means that the change occurs because corruption changed the secondary education effect and not the direct effect of higher education. ECA = Eastern and Central Europe and Central Asia; CIS = Commonwealth of Independent States. 
being poor by .18 on average, ranging from a low of .09 in lower-income Asian countries to a high of .28 in high-income Asian countries. In all regions, higher education decreases the probability of being poor relative to the completion of secondary education on average by .17 or about 4.25 percent per year of higher education. Within the ECA region, higher education is most effective in keeping people out of poverty in the CIS region, where higher education decreases the probability of being poor by about 10 percent per year of investment.

Higher education becomes a less effective means to high income if there is significant perceived corruption in education in Africa, Western Europe, North America, and the high-income countries of Asia. In Africa, the marginal effect of higher education on the probability of high income falls by about 70 percent from .21 to .06 under maximum corruption $(C=5)$. In Western Europe the marginal effect of higher education on the probability of high income falls by about 25 percent from .165 to .125 under maximum corruption.

Corruption in education adversely affects the relative ability of higher education to keep people out of poverty in Western Europe, low-income Asia, Africa, Latin America, and ECA. In the ECA region, we find this effect most pronounced in the CIS countries. At maximum corruption within the CIS, corruption increases the probability that those with higher education are poor. With no corruption, higher education reduces the probability of low income by 40 percent in comparison to completion of secondary education. With maximum corruption, the marginal effect of higher education on the probability of low income falls to -.11 ; this is a 70 percent decrease in the ability of higher education over secondary education to keep people out of poverty, and the number of highly educated persons who live in poor households increases if there is significant corruption in education. Higher education is also a less effective means to reduce poverty when there is significant corruption in education in Africa and the lower-income countries of Asia, but this occurs because corruption makes secondary education more attractive. In Latin America, corruption has the opposite effect on higher education and makes it less likely that highly educated persons will live in low-income households.

The results suggest that corruption in education does change the ability of education to increase income. In general, corruption in education has its largest effects on high income in the higher-income countries of Asia, North America, and Western Europe, while in lower-income countries corruption has its largest effects on low income. With a few exceptions, higher education increases income, but this effect is significantly lower when corruption in education is pervasive. ${ }^{29}$

\footnotetext{
${ }^{29}$ It is possible that other institutional quality factors may influence this result and could be the focus of future analysis. 
We next turn our attention to the effect that education corruption might have on the economic returns to investments in education. The literature on the internal rates of return to education in ECA is summarized in Kathryn Anderson and Michael Cain (2006). From that review, we assume a benchmark internal rate of return to higher education of .2 when there is no significant corruption in higher education. In the Kyrgyz Republic, the typical secondary school graduate earns about $\$ 600$ a year, 4 years of college education increases earnings 20 percent, and a college graduate earns on average $\$ 720$ per year with 4 years of college education. If earned income grows at 3 percent per year, the discount rate is 3 percent, and he works for 40 years, he accumulates about $\$ 28,800$ in lifetime earned income with college education, or $\$ 4,800$ more than with secondary education. ${ }^{30}$ This calculation assumes no change in the value of experience with corruption. If pervasive corruption reduces the marginal return to higher education by 70 percent from .2 to .06 , the college graduate earns on average 6 percent more than the typical secondary school graduate, or $\$ 636$ a year. Over 40 years he accumulates $\$ 25,440$, or $\$ 1,440$ more than those with secondary education. Corruption reduces lifetime income accruing to the investment in higher education by $\$ 2,360$, or 50 percent of the uncorrupted higher-education advantage.

This calculation is not based on the direct estimation of economic cost. The result of this experiment, however, is consistent with evidence from the Kyrgyz Republic obtained through recent interviews with firm managers, government officials, and university faculty in five diverse oblasts. ${ }^{31}$ One hightechnology firm required employees to have a college degree and paid about $\$ 200$ a month for an entry-level position. Employees were recruited from four universities: American University of Central Asia, Manas University (Turkish-Kyrgyz University), Slavonic University (Russian-Kyrgyz University), and Kyrgyz National University. Three of these universities were connected to foreign institutions and had the lowest levels of reported corruption. Students from regional and smaller state universities were not considered. In addition, this firm and all other firms that recruited college-trained employees required a 3-month apprenticeship or internship period during which managers indicated that students who had little ability would be dismissed. In some of these firms and at least one government ministry, written tests were administered before anyone was employed. The test separated students from state universities who had bought their degrees from students who were truly educated. Finally, most of these firms reported that they use

\footnotetext{
${ }^{30}$ A 3 percent growth in earnings per year is a common estimate of the effect of experience in the transitioning states.

${ }^{31}$ All the firms interviewed received management consulting through the Employment Development Program sponsored by the U.S. Agency for International Development through Pragma Corporation and constitute a convenience sample of enterprises.
} 
performance incentives when possible. They reward their employees with bonuses or piece-rate pay in addition to monthly salary income.

The use of these sorting devices imposes additional costs on firms and is related to the uncertainty attached to the quality of education attained by students. ${ }^{32}$ Most important, among the firms in which we conducted interviews, students from highly corrupt universities were not considered for technical and professional private-sector jobs and even some government jobs and were screened out of jobs in foreign enterprises. If the best alternative for students from corrupt programs is employment in the government with starting salaries of $\$ 50-70$ a month, the wage losses are enormous. If students from corrupt educational programs sort into government jobs with the potential for bribes, the private income costs of corruption are reduced, but the social costs remain.

\section{Summary and Policy Implications}

Although educational corruption existed under the Soviet Union, we hypothesize that it was modest by comparison to the level today. Corruption in education increased because of decentralized decision making, which makes agents more difficult to control, the proliferation of university owners and purposes, and the inexperience with enforcing professional norms without traditional sanctions. Moreover, private education and tuition-based public education are new, and there is little experience in managing the expectations of fee-paying students. ${ }^{33}$

This article illustrates the extent of higher-education corruption by citing student surveys in six countries-the Kyrgyz Republic, Kazakhstan, Croatia, Moldova, Serbia, and Bulgaria. These surveys suggest that corruption varies in accordance with the market demand for the subject of study, with higher frequencies of corruption found in the subjects in highest demand. Also, corruption is more likely to be found in local universities with local professional codes of conduct and less likely to be found in universities accredited in Europe or North America.

We hypothesize that the cost to a student who attends a university characterized by a high level of corruption would be the equivalent of sacrificing the economic impact of higher-education quality. Using data from Transparency International on perceptions of corruption in education in 68 countries, we find that a nation's perceived corruption significantly reduces the payoff to higher education; when corruption is pervasive, highly educated

\footnotetext{
${ }^{32}$ The next stage in the effort to research the cost of higher-education corruption might be a carefully considered calculation of the monetary cost of these selection mechanisms to the private and public sectors.

${ }^{33}$ Where professional integrity is not based on tradition, "private" university may imply that all educational products are for sale. Codes of conduct and legal agreements spelling out the rights and obligations of students and faculty are only now beginning to appear.
} 
persons are much less likely to report high income in high-income countries and Africa and are more likely to be poor in ECA, Africa, and lower-income countries of Asia. The change in these high-income returns to higher education ranges from 25 to 70 percent.

Many of the countries of the ECA region are participating in the Bologna Process with members of the European Union. One objective of that process is to make university degrees equivalent in hopes of facilitating transfer students and greater mobility in the labor market. Universities or university systems with reputations for corruption, whether experienced or perceived, will likely end the Bologna Process. Were this process to actually take effect, it would constitute the educational equivalent in the European Union of unilateral disarmament. It is difficult to imagine why a country or a university with a high reputation would allow its degrees to be made equivalent to those of a university or a university system with a reputation for corruption.

A final implication of education corruption is for development assistance agencies, many of which make investments in higher education. These agencies may have to rethink their strategies when it is understood that the impact of their investments could be significantly reduced if made in higher-education systems with high levels of perceived corruption.

There are many mechanisms that a country or a university needs to adopt to lessen the possibility of corruption and to lower the perception that it is corrupt. These include codes of conduct for faculty, administrators, and students; statements of honesty on public Web sites; university "courts" to hear cases of misconduct; and annual reports to the public on changes in the number and types of incidents. These mechanisms may well be requirements for universities in those parts of the world hoping to have their degrees declared equivalent to those of universities in the European Union or having the support of international development assistance agencies.

However, the first step to effective policy intervention is to acquire information about the experience and cost of corruption. We recommend regular surveys of students such as those reported here. ${ }^{34}$ In one country, with surveys at two points in time, the decline in corruption was significant, suggesting that when the possibility of exposure and professional embarrassment is real, the propensity to engage in corruption declines.

\section{References}

Ahlin, Christopher, and Pataki Bose. 2007. "Bribery, Inefficiency and Bureaucratic Delay." Journal of Development Economics 84 (1): 465-86.

Anderson, Kathryn, and Michael Cain. 2006. "The Importance of Social Investments for Economic Growth and Governing in Transitioning States: A Survey of Recent

${ }^{34}$ A complete list of interventions to lower the incidence of education corruption can be found in Stephen Heyneman (2004a). 
Evidence.” Report prepared for U.S. Agency for International Development through Aguirre International, Washington, DC.

Bardhan, Pranad. 1997. "Corruption and Development: A Review of Issues." Journal of Economic Literature 35 (3): 1320-46.

Becker, Gary S., and George J. Stigler. 1974. "Law Enforcement, Malfeasance, and Compensation of Enforcers." Journal of Legal Studies 3 (1): 1-19.

Behrman, Jere R., and Nancy Birdsall. 1983. "The Quality of Schooling: Quantity Alone Is Misleading." American Economic Review 73 (5): 928-46.

Braxton, John M., and A. E. Bayer. 1999. Faculty Misconduct in Collegiate Teaching. Baltimore: Johns Hopkins University Press.

Brewer, Dominic J., Eric R. Eide, and Ronald G. Ehrenberg. 1999. "Does It Pay to Attend an Elite Private College? Cross-Cohort Evidence on the Effects of College Type on Earnings." Journal of Human Resources 34 (1): 104-23.

Collins, Randall. 1979. The Credential Society: An Historical Sociology of Education and Stratification. New York: Wiley.

Dale, Stacy B., and Alan B. Krueger. 2002. "Estimating the Payoff to Attending a More Selective College: An Application of Selection on Observables and Unobservables." Quarterly Journal of Economics 117 (4): 1491-1527.

Griliches, Zvi, and William M. Mason. 1972. "Education, Income and Ability." Journal of Political Economy 80 (3, pt. 2): S74-S103.

Hause, John C. 1971. "Ability and Schooling as Determinants of Lifetime Earnings or If You're So Smart, Why Aren't You Rich?” American Economic Review 61 (2): 289-98.

Hause, John C. 1972. "Earnings Profile: Ability and Schooling." Journal of Political Economy 80 (3, pt. 2): S108-S138.

Heyneman, Stephen P. 2002/3. "Defining the Influence of Education on Social Cohesion." International Journal of Educational Policy, Research and Practice 3 (Winter): 73-97.

Heyneman, Stephen P. 2003. "Education and Misconduct." In Encyclopedia of Education,vol. 5, ed. James Guthrie. New York: Macmillan.

Heyneman, Stephen P. 2004a. "Education and Corruption." International Journal of Educational Development 24 (6): 638-48.

Heyneman, Stephen P. 2004b. "International Education Quality." Economics of Education Review 23 (4): 441-52.

Heyneman, Stephen P. 2005. "Organizations and Social Cohesion." Peabody Journal of Education 80 (3-4): 1-8.

Hilmer, Michael J. 2002. "Human Capital Attainment, University Quality, and EntryLevel Wages for College Transfer Students." Southern Economic Journal 69 (2): 457-69.

Hutchinson, Francis, Tom Lavens, and Marie Wolkens. 2005. "Report on the Transparency International Global Corruption Barometer 2005." Policy and Research Department, Transparency International-International Secretariat, Berlin.

James, Estelle, Nabeel Alsalam, Joseph C. Conaty, and Duc-Le To. 1989. "College Quality and Future Earnings: Where Should You Send Your Child to College?" American Economic Review 79 (2): 247-52.

Kingston, Paul William, and Lionel S. Lewis. 1990. "Introduction: Studying Elite Schools in America." In The High-Status Track: Studies of Elite Schools and Stratifi- 
cation, ed. Paul William Kingston and Lionel S. Lewis. Albany: State University of New York Press.

Kingston, Paul William, and John C. Smart. 1990. "The Economic Payoff of Prestigious Colleges." In The High-Status Track: Studies of Elite Schools and Stratification, ed. Paul William Kingston and Lionel S. Lewis. Albany: State University of New York Press.

Link, Charles R. 1973. "The Quantity and Quality of Education and Their Influence on Earnings: The Case of Chemical Engineers." Review of Economics and Statistics 55 (2): 241-47.

McGuinness, Seamus. 2003a. "Graduate Overeducation as a Sheepskin Effect: Evidence from Northern Ireland." Applied Economics 35 (5): 597-608.

McGuinness, Seamus. 2003b. "University Quality and Labour Market Outcomes." Applied Economics 35 (18): 1943-55.

Mueller, Ralph O. 1988. "The Impact of College Selectivity on Income for Men and Women." Research in Higher Education 29 (2): 175-91.

Noah, Harold J., and Max A. Eckstein. 2001. Fraud and Education: The Worm in the Apple. Lanham, MD: Rowman \& Littlefield.

Ono, Hiroshi. 2004. "College Quality and Earnings in the Japanese Labor Market." Industrial Relations 43 (3): 595-617.

Posliyski, S., and V. Vatev. 2003. "Survey Report: Corruption in Higher Education." Photocopy, Anti-Corruption Student Network in Southeastern Europe, Sofia, Bulgaria.

Psacharopoulos, George. 1974. “College Quality as a Screening Device." Journal of Human Resources 9 (4): 556-58.

Rose-Ackerman, Susan. 1975. "The Economics of Corruption." Journal of Public Economics 4 (2): 187-203.

Rumberger, Russell W., and Scott L. Thomas. 1993. "The Economic Returns to College, Major, Quality, and Performance: A Multilevel Analysis of Recent Graduates." Economics of Education Review 12 (1): 1-19.

Shleifer, Andrei, and Daniel Treisman. 2005. "A Normal Country: Russia after Communism." Journal of Economic Perspectives 19 (1): 151-74.

Shleifer, Andrei, and Robert W. Vishny. 1993. "Corruption." Quarterly Journal of Economics 108 (3): 599-617.

Silova, Iveta, Mark Johnson, and Stephen Heyneman. 2007. "Education and the Crisis of Social Cohesion in Azerbaijan and Central Asia." Comparative Education Review 51 (2): 159-80.

Solmon, Lewis C. 1975. "The Definition of College Quality and Its Impact on Earnings." Explorations in Economic Research 2 (4): 537-87.

Solmon, Lewis C., and Paul Wachtel. 1975. "The Effect on Income of Type of College Attended." Sociology of Education 48 (1): 75-90.

Sosa, Luis A. 2004. "Wages and Other Determinants of Corruption." Review of Development Economics 8 (4): 597-605.

Strayer, Wayne. 2002. "The Returns to School Quality: College Choice and Earnings." Journal of Labor Economics 20 (3): 475-503.

Transparency International. 2006. "Transparency International Corruption Perceptions Index 2006.” Press release, http://www.transparency.org/policy_research/ surveys_indices/cpi/2006. 
van Rijckeghem, Caroline, and Beatrice Weber. 2001. "Bureaucratic Corruption and the Rate of Temptation: Do Wages in the Civil Service Affect Corruption and by How Much?" Journal of Development Economics 65 (2): 307-31.

Wales, Terence J. 1973. "The Effect of College Quality on Earnings from the NBERThorndike Data." Journal of Human Resources 8 (3): 306-17.

Welch, Finis. 1966. "Measurement of the Quality of Schooling." American Economic Review 56 (3): 379-92. 